\title{
Regulation of COX-2 expression and epithelial-to-mesenchymal transition by hypoxia-inducible factor-1 $\alpha$ is associated with poor prognosis in hepatocellular carcinoma patients post TACE surgery
}

\author{
MINGSHENG HUANG ${ }^{1-3^{*}}$, LONG WANG $^{4 *}$, JUNWEI CHEN $^{1}$, MINGJUN BAI $^{1}$, \\ CHUREN ZHOU ${ }^{1}$, SUJUAN LIU ${ }^{1}$ and QU LIN ${ }^{5}$
}

\author{
${ }^{1}$ Department of Radiology, The Third Affiliated Hospital, ${ }^{2}$ Department of Interventional Radiology, Ling-nan Hospital, \\ ${ }^{3}$ Interventional Radiology Institute, Sun Yat-sen University; ${ }^{4}$ Department of Interventional Radiology, \\ Guangzhou First People's Hospital, Guangzhou Medical University; ${ }^{5}$ Department of Medical Oncology, \\ The Third Affiliated Hospital, Sun Yat-Sen University, Guangzhou 510630, P.R. China
}

Received December 26, 2015; Accepted February 6, 2016

DOI: 10.3892/ijo.2016.3421

\begin{abstract}
Currently, it is not entirely clear whether hypoxiainducible factor- $1 \alpha$ (HIF-1 $\alpha)$ is involved in the regulation of COX-2 expression and epithelial-to-mesenchymal transition (EMT), and whether these events affect the prognosis of hepatocellular carcinoma (HCC) patients treated with transcatheter arterial chemoembolization (TACE). In this report the relationship between HIF-1 $\alpha$ and COX-2 protein expression, EMT in tumor specimens from HCC patients after TACE surgery and the clinical significance of HIF-1 $\alpha$ and COX-2 expression were analyzed using statistical approaches. HepG2 cells treated with $\mathrm{CoCl}_{2}$ was employed as a hypoxia cell model in vitro to study hypoxia-induced HIF- $1 \alpha$, COX-2 expression, and EMT alteration. The results showed that HIF- $1 \alpha$ and COX-2 protein expression increased in HCC tissues after TACE surgery. Moreover, there was positive correlation between upregulation of HIF-1 $\alpha$ and COX-2. Elevated expression of HIF-1 $\alpha$ increased both Snail and Vimentin protein expression, while it reduced E-cadherin protein expression. It was further verified that hypoxia enhanced protein expression of HIF-1 $\alpha$ and COX-2 in HepG2 cells treated with $\mathrm{CoCl}_{2}$. Upregulation of HIF-1 $\alpha$ and COX-2, together with EMT alteration resulted in increased migration and invasion of HepG2 cells under
\end{abstract}

Correspondence to: Dr Mingsheng Huang, Department of Radiology, The Third Affiliated Hospital, Sun Yat-sen University, 600 Tianhe Road, Guangzhou 510630, P.R. China

E-mail: mingshenghh@163.com

Dr Qu Lin, Department of Medical Oncology, The Third Affiliated Hospital, Sun Yat-Sen University, Guangzhou 510630, P.R. China

E-mail: linqudr@sina.com

${ }^{*}$ Contributed equally

Key words: hepatocellular carcinoma, hypoxia, hypoxia-inducible factor-1 $\alpha$, COX-2, epithelial-to-mesenchymal transition hypoxia. In conclusion, TACE surgery results in aggravated hypoxia status, leading to increased HIF-1 $\alpha$ protein expression in HCC tissue. To adapt to hypoxic environment, HIF-1 $\alpha$ stimulates COX-2 protein expression and promotes EMT process in hepatocellular cancer cells, which enhances HCC invasion and metastasis, and might contribute to poor prognosis in HCC patients post TACE treatment.

\section{Introduction}

Hepatocellular carcinoma (HCC) is the sixth most common cancer and the third leading cause of cancer-related deaths worldwide. Most HCC patients are diagnosed with the tumor at medium- or late-stage because of poor diagnosis (1-4). Transcatheter arterial chemoembolization (TACE) is considered as an important palliative therapy for late-stage HCC patients (5-7). Ideally, during the TACE treatment, iodine oil should achieve complete embolization and thus tumor necrosis. However, TACE treatment does not attain complete tumor necrosis in the majority of HCC patients, while the hypoxia status after TACE treatment plays a key role in HCC recurrence and metastasis $(8,9)$.

Previous studies have shown that low oxygen environments are prevalent in tumors (10-12). Hypoxia-inducible factor (HIF) is a transcription factor upregulated in response to hypoxia. It is composed of HIF- $1 \alpha$ and HIF- $1 \beta$ subunit, and the HIF-1 $\alpha$ unit is vital to HIF-1 stability and expression level (13). HIF-1 $\alpha$ is involved in transcriptional regulation of a variety of target genes in the growth of various types of cancers. TACE is a common therapeutic approach. However, it might aggravate hypoxia and thus affects HIF-1 $\alpha$ protein expression, promoting growth, invasion and metastasis of residual cancer, which is probably the main reason influencing the long-term curative effects for TACE (14-16).

Cyclooxygenase (COX) plays a key role in physiological and pathological regulation $(17,18)$. It consists of two subunits: COX-1 and COX-2. COX-2 is not expressed in physiological condition, while its expression is induced by pathological stimuli, such as cancer, endotoxin and hormones $(19,20)$. It 
is well documented that COX-2 accelerates cancer invasion and metastasis through inhibiting cancer cell apoptosis and promoting tumor angiogenesis (21-23). High expression of COX-2 is closely correlated with poor prognosis for various types of cancers (24-26). The role of high expression of HIF-1 $\alpha$ and $\mathrm{COX}-2$ in clinical prognosis of HCC patients after TACE remains to be completely elucidated.

Epithelial-to-mesenchymal transition (EMT) is a process in which epithelial cells are transmitted to mesenchymal cells that have higher ability of migration $(27,28)$. EMT is regulated by HIF- $1 \alpha$ and COX-2, playing an important role in tumor occurrence and metastasis $(29,30)$. The relationship between EMT and HIF-1 $\alpha$, COX-2 protein expression in HCC tissue after TACE surgery is hardly investigated. In this study, we detected HIF-1 $\alpha$ and COX-2 protein expression in HCC tissues after TACE surgery and in HepG2 cells treated with hypoxia in vitro. In addition, the relationship between EMT and HIF-1 protein expression was evaluated. This study aimed to provide clues to increasing survival time for HCC patients post TACE.

\section{Materials and methods}

Clinical characteristics and medical records. This study complied with the Declaration of Helsinki and the ethics committee of the Third Affiliated Hospital, Sun Yat-Sen University approved the study protocol. Informed consent from all participants was obtained before the initial coronary angiography.

Paired cancer tissues and adjacent normal liver tissues from HCC patients undergoing TACE surgery were prospectively collected between November 2006 and September 2013 at the Third Affiliated Hospital, Sun Yat-Sen University. A total of $51 \mathrm{HCC}$ patients were enrolled in this study, including 48 males and 3 females, and their age ranged from 29 to 72 years (median, 50.5 years). All HCC specimens were procured and processed following standard procedures. The tissue was fixed using $10 \%$ formaldehyde solution, embedded within paraffin, and then sectioned into $5-\mu \mathrm{m}$ slices. The general information of all patients including name, gender and age was collected. Other clinical characteristics including AFP level before surgery, liver function and medical imaging data (CT or MRI), tumor size, tumor number, BCLC stage of cancer, presence of cancer capsule, the presence of vascular invasion and distant metastasis were also recorded. Cancer tissues from $61 \mathrm{HCC}$ patients without TACE surgery were collected and served as controls. Postoperative follow-up was carried out regularly through telephone and letter. The mean postoperative follow-up period was 36.0 months (range, 3.0-75.0 months). Overall survival was calculated from the date of surgery to the date of death or the last follow-up.

Culture of HepG2 cells and hypoxia treatment. HepG2 cells were cultured in DMEM medium with $10 \%$ fetal calf serum (FBS, Gibco, USA) at $37^{\circ} \mathrm{C}$ in a humidified atmosphere containing $5 \% \mathrm{CO}_{2}$. Different concentrations of $\mathrm{CoCl}_{2}$ (Sigma, USA) was added into culture medium to mimic the hypoxic microenvironment (31).

CCK-8 assay. HepG2 cells were detached with trypsin and seeded on a 96 -well plate $\left(1 \times 10^{4}\right.$ cells/well $)$. After culture in DMEM culture medium supplemented with 10\% FBS to allow cells become adherent, cells were treated with 0 , 100, 200 and $300 \mu \mathrm{M} \mathrm{CoCl}_{2}$ diluted in DMEM/10\% FBS for 24 h. Cells without $\mathrm{CoCl}_{2}$ treatment served as controls. Then $10 \mu \mathrm{l}$ CCK-8 solution was added into each well and the plate was incubated for additional $1 \mathrm{~h}$. Afterwards, the absorbance at $450 \mathrm{~nm}$ was measured using a microplate reader. Wells without addition of CCK-8 solution were taken as the blank. The cell viability was calculated using the formula: Cell viability $(100 \%)=\left(\right.$ mean OD of $\mathrm{CoCl}_{2}$ group - mean OD of blank group)/mean OD of control group - mean OD of blank group) x 100. We performed 3 parallel repeats in each group. This experiment was carried out independently 3 times.

Quantitative reverse transcription PCR ( $q R T-P C R)$ analysis. HepG2 cells $\left(10^{5}\right.$ cell $\left./ \mathrm{ml}\right)$ were seeded in a 6 -well plate and treated with $0,100,200$ and $300 \mu \mathrm{M} \mathrm{CoCl}_{2}$ diluted in DMEM/ $10 \%$ FBS for 12 and $24 \mathrm{~h}$. Total RNA was extracted using TRIzol (Invitrogen, USA) according to the manufacturer's instructions. Total RNA $(1 \mu \mathrm{g})$ was reverse transcribed into cDNA with a reverse transcription kit (Promega, USA). The PCR reaction was carried out in a total of $20 \mu 1$ reaction mixture using Invitrogen $\mathrm{PCR}$ kit and the reactions were performed as follows, $50^{\circ} \mathrm{C}$ for $2 \mathrm{~min}, 95^{\circ} \mathrm{C}$ for $2 \mathrm{~min}$, followed by 40 cycles of $95^{\circ} \mathrm{C}$ for $15 \mathrm{sec}$ and $60^{\circ} \mathrm{C}$ for $32 \mathrm{sec} . \beta$-actin was used as the endogenous reference to measure the relative expression levels of HIF-1 $\alpha$ and COX-2. The primer sequences are shown in Table I.

Western blot detection. Cells were lyzed in RIPA buffer and centrifuged to extract total protein. Protein concentration of samples was determined using the Bradford assay method. Sample protein $(30 \mu \mathrm{g})$ was separated in $8 \%$ SDS-PAGE and transferred to PVDF membrane. The membrane was blocked with 5\% skim milk in TBST, and then incubated with primary antibodies overnight at $4^{\circ} \mathrm{C}$ using mouse anti-rat HIF-1 $\alpha$ polyclonal antibody (Santa Cruz, USA, dilution, 1:300), mouse anti-rat COX-2 polyclonal antibody (Santa Cruz, 1:500) and mouse anti-rat $\beta$-actin polyclonal antibody (Santa Cruz, 1:2,000). The next day, after 3 washes in TBST, the membrane was incubated with goat anti-mouse HRP-labeled secondary antibody (Santa Cruz, 1:5,000) for $1 \mathrm{~h}$ at room temperature (RT). Bands were developed with an ECL chemiluminescence reagent system (Beyotime, China).

Invasion assay. Melting Matrigel (50 mg/1, BD, USA) was diluted 1:6 with pre-cooled serum-free DMEM culture medium, which was then used to coat the upper membrane surface of the top chamber. Then the Transwell plate was incubated at $37^{\circ} \mathrm{C}$ for $1.5 \mathrm{~h}$. HepG 2 cells were digested using trypsin, centrifuged at $130 \mathrm{x}$ g for $5 \mathrm{~min}$ and re-suspended in serum-free DMEM containing 0 or $200 \mu \mathrm{M} \mathrm{CoCl}_{2}$. Cells/ well $\left(1 \times 10^{5}\right)$ were seeded into the top chamber. DMEM $(500 \mu 1) / 10 \%$ FBS was added in the bottom chamber. After 24-h incubation, the top chamber was taken out and fixed using $4 \%$ paraformaldehyde solution for $30 \mathrm{~min}$. After 3 washes with PBS, cells on the upper membrane surface were removed using a cotton swab. Cells on the bottom membrane surface were stained with Giemsa for $8 \mathrm{~min}$ followed by washing with PBS, 3 times for $5 \mathrm{~min}$. The number of cells 
Table I. The primer sequences.

\begin{tabular}{lll}
\hline HIF- $1 \alpha$ & AAGCACTAGACAAAGCTCACCTG & TTGACCATATCGCTGTCCAC \\
COX-2 & TTGACCATATCGCTGTCCAC & TTGACCATATCGCTGTCCAC \\
$\beta$-actin & TTGACCATATCGCTGTCCAC & TCGGCCACATTGTGAACTTT \\
\hline
\end{tabular}

Table II. HIF-1 $\alpha$ and COX-2 protein expression in cancer tissues from HCC patients after TACE surgery.

\begin{tabular}{lcc}
\hline & Positive rate of HIF-1 $\alpha$ & Positive rate of COX-2 \\
\hline Liver cancer tissue of HCC patient after TACE surgery & $49.0 \%(26 / 51)$ & $56.8 \%(29 / 51)$ \\
Adjacent normal liver tissue of HCC patient after TACE surgery & $21.6 \%(11 / 51)$ & $25.5 \%(13 / 51)$ \\
Liver cancer tissue in HCC patient without TACE surgery & $34.4 \%(21 / 61)$ & $47.5 \%(23 / 61)$ \\
\hline
\end{tabular}

on bottom membrane surface (invading cells) was calculated randomly under a microscope in highly magnified field (q). The experiment was repeated 3 times.

Wound-healing assay. Cells $(1 \mathrm{ml})$ at a density of $4 \times 10^{5}$ cells $/ \mathrm{ml}$ were seeded into each well of a 6-well plate and cultured to $100 \%$ confluence. The monolayer of cells was then scratched with a $10-\mu l$ pipette tip to create a wound gap. After 3 washes with PBS to remove suspended cells, the plate was placed back into an incubator for incubation for an additional 24 and $48 \mathrm{~h}$. Images were taken at 0,24 and $48 \mathrm{~h}$ after the wound was induced to observe the healing of the wound gap.

Immunohistochemistry detection. Tissue slices $(4 \mu \mathrm{m})$ were deparaffinized using dimethylbenzene, 2 times for $5 \mathrm{~min}$ and rehydrated using gradient ethanol. Then slices were soaked in deionized water for $5 \mathrm{~min}$ and dried using absorbent paper. Antigen retrieval was carried out by heating the sample in a microwave oven. After cooled down, slices were treated with $3 \% \mathrm{H}_{2} \mathrm{O}_{2}$ at room temperature for $10 \mathrm{~min}$. Then slices were washed with PBS and blocked with 3\% BSA in PBS for $1 \mathrm{~h}$. After blocking, slices was incubated with primary antibody (1:50-200) at $4^{\circ} \mathrm{C}$ overnight, and subsequently incubated with HRP-labeled secondary antibody (Dako, Canada) at $37^{\circ} \mathrm{C}$ for $1 \mathrm{~h}$. The slices were then treated with a chromogen, 3,3'-diaminobenzidine tetrahydrochloride (DAB) and counterstained with hematoxylin for $45 \mathrm{sec}$. Finally, slices were washed with ultrapure water, dehydrated with gradient ethanol, deparaffinized using dimethylbenzene for $10 \mathrm{~min}$, dried and sealed.

Statistical analysis. Data were analyzed using SPSS 13.0 software. Quantity data were expressed as mean \pm SD. The Student's t-test was used when 2 groups were compared. Fisher's exact test was used to analyzed the difference between HIF-1 $\alpha$, COX-2 and clinical pathological data. Spearman correlation coefficient was used to determine the relationship between HIF- $1 \alpha$ and COX-2 protein expression. Survival analysis was performed using Kaplan-Meier estimate. The survival curves between different groups were analyzed using log-rank test. After the univariate analysis for 14 factors, only variables with $\mathrm{P}$-value $<0.05$ were included in the multivariate analysis using the Cox proportional hazards model to identify the independent prognostic factors for overall survival. $\mathrm{P}<0.05$ was considered statistically significant.

\section{Results}

Increased expression of HIF-1 $\alpha$ and COX-2 protein in HCC tissue after TACE surgery. Immunohistochemistry experimental results showed that HIF-1 $\alpha$ protein expression in liver cancer tissue significantly increased in 51 cases of HCC patients post TACE, compared with corresponding adjacent noncancerous liver tissue (Fig. 1 and Table II, $\mathrm{P}=0.001$ ). The positive rate of HIF-1 $\alpha$ protein expression in liver cancer tissue from HCC patients without TACE surgery was significantly lower than that in liver cancer tissue from HCC patients post TACE (Fig. 1 and Table II, P=0.013).

In Fig. 1 and Table II, the immunohistochemistry results showed that COX-2 protein expression in liver cancer tissue of 51 cases of HCC patients post TACE was higher than that in corresponding adjacent noncancerous liver tissue (Fig. 2 and Table II, $\mathrm{P}=0.001)$. The positive rate of $\mathrm{COX}-2$ protein expression in liver cancer tissue from HCC patients without TACE surgery was significantly lower than that in liver cancer tissue from HCC patients post TACE (Fig. 2 and Table II, $\mathrm{P}=0.034$ ).

The relationship between HIF-1 $1 \alpha$, COX-2 and clinicopathologic variables. After analysis by Fisher's exact test, our data showed that HIF-1 $\alpha$ protein level was significantly higher in groups of BCLC stage A and ALT before surgery $\geq 40 \mathrm{U} / 1$ than groups of BCLC stage $\mathrm{B}+\mathrm{C}$ and ALT before surgery $<40 \mathrm{U} / 1$, respectively ( $\mathrm{P}=0.011$ and 0.028 , respectively). However, increased protein expression of HIF-1 $\alpha$ had no significant difference in groups in terms of age, gender, Childs classification, AFP level, tumor size, tumor number and presence of cancer capsule (Table III). COX-2 protein expression significantly increased in HCC patient with vascular invasion and intrahepatic metastasis ( $\mathrm{P}=0.021$ and 0.048 , respectively), 


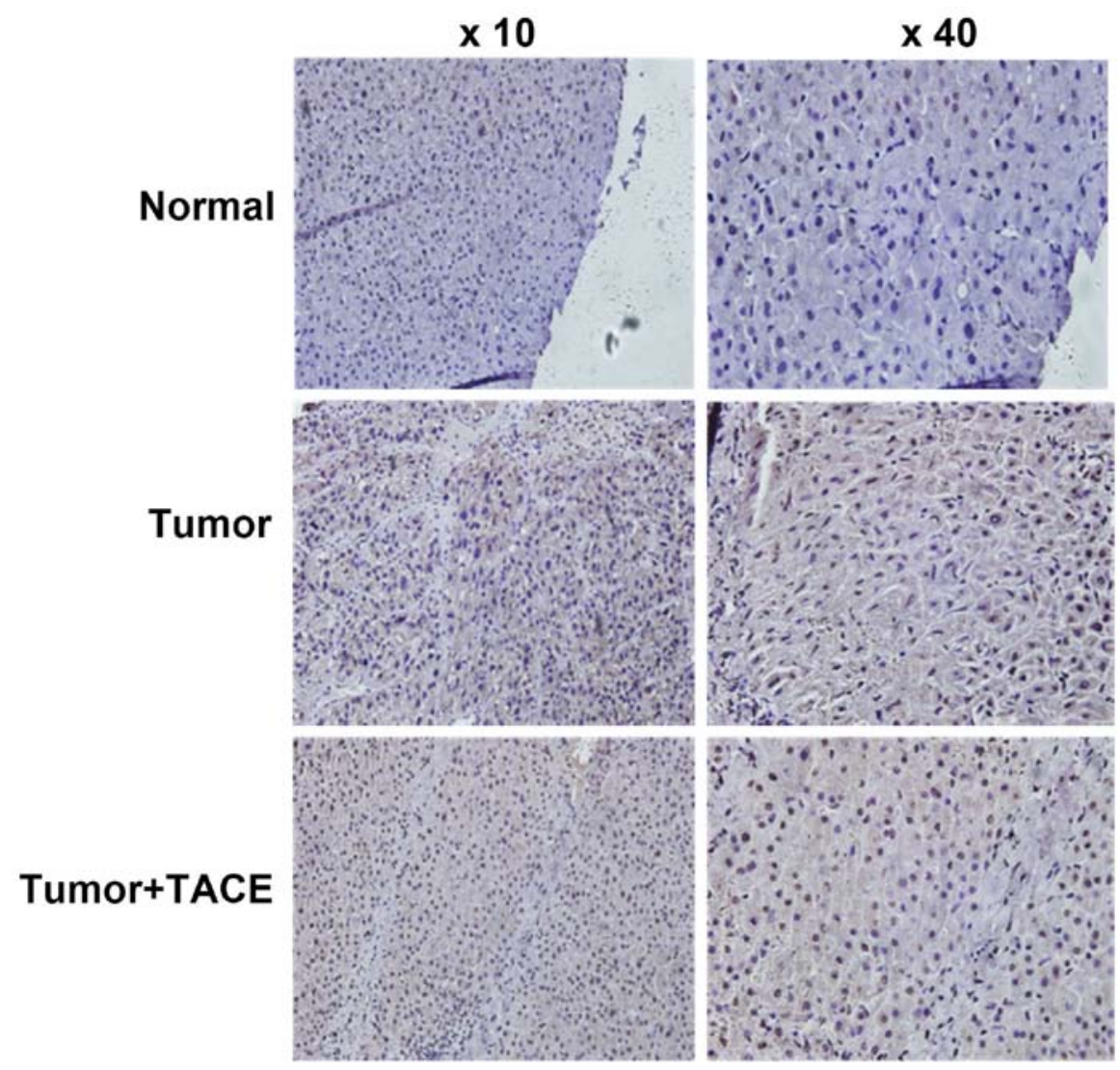

Figure 1. HIF-1 $\alpha$ protein expression in cancer tissue from an HCC patient post TACE surgery was significantly higher than that of adjacent normal liver tissue and cancer tissue from an HCC patient without TACE surgery.

$\mathbf{x 1 0}$

Normal

Tumor
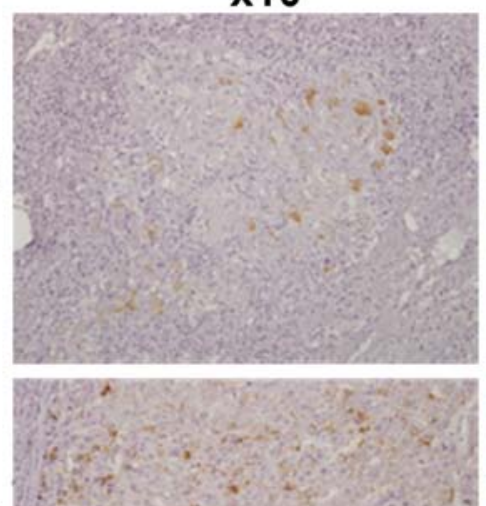

Tumor+TACE

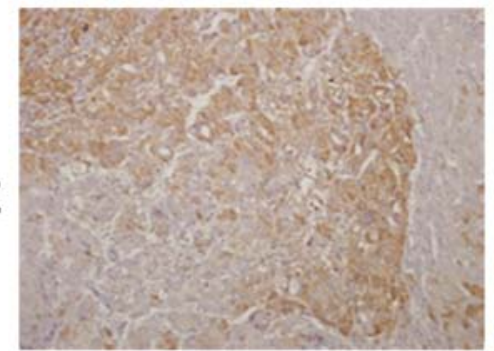

$x 40$
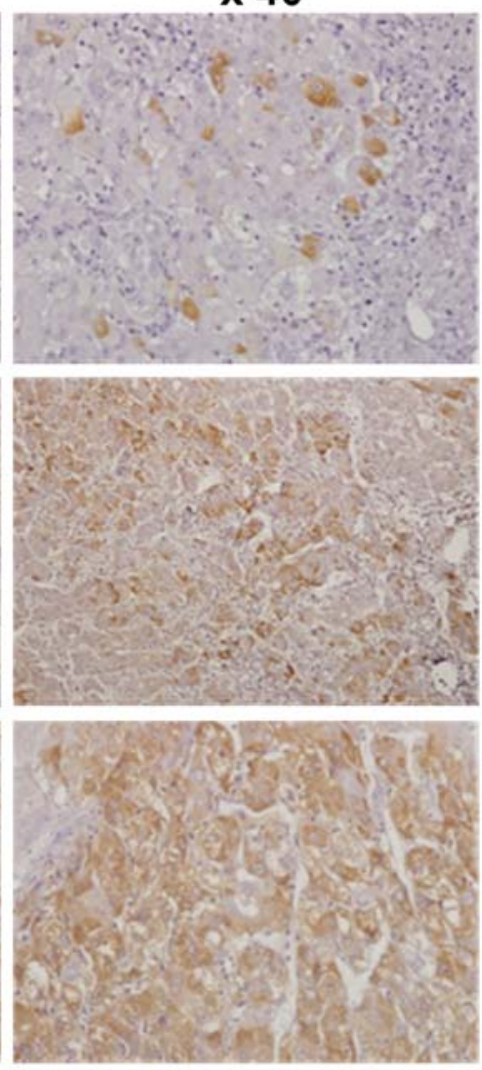

Figure 2. COX-2 protein expression in cancer tissue from an HCC patient post TACE surgery was significantly higher than that of adjacent normal liver tissue and cancer tissue from an HCC patient without TACE surgery. 
Table III. HIF- $1 \alpha$ expression was statistically different between HCC patients in BCLC stage A and BCLC stage B+C, and patients with high and low level of ALT before surgery $(\mathrm{P}=0.011$, $\mathrm{P}=0.028$, respectively).

\begin{tabular}{|c|c|c|c|c|c|c|c|c|c|}
\hline \multirow[b]{2}{*}{$\begin{array}{l}\text { Clinical } \\
\text { characteristics }\end{array}$} & \multirow[b]{2}{*}{$\begin{array}{l}\text { No. of } \\
\text { patients }\end{array}$} & \multicolumn{2}{|c|}{ HIF- $1 \alpha$} & \multirow[b]{2}{*}{ P-value } & \multirow[b]{2}{*}{$\begin{array}{l}\text { Clinical } \\
\text { characteristics }\end{array}$} & \multirow[b]{2}{*}{$\begin{array}{l}\text { No. of } \\
\text { patients }\end{array}$} & \multicolumn{2}{|c|}{$\mathrm{COX}-2$} & \multirow[b]{2}{*}{ P-value } \\
\hline & & Positive & Negative & & & & Positive & Negative & \\
\hline Age & 51 & & & & Age & 51 & & & \\
\hline$>60$ & 13 & 11 & 2 & 0.103 & $>60$ & 13 & 11 & 2 & 0.059 \\
\hline$\leq 60$ & 38 & 14 & 24 & & $\leq 60$ & 38 & 18 & 20 & \\
\hline Gender & 51 & & & & Gender & 51 & & & \\
\hline Male & 48 & 22 & 26 & 0.110 & Male & 48 & 27 & 21 & 0.604 \\
\hline Female & 3 & 3 & 0 & & Female & 3 & 2 & 1 & \\
\hline Tumor size & 51 & & & & Tumor size & 51 & & & \\
\hline$\geq 50 \mathrm{~mm}$ & 27 & 15 & 12 & 0.239 & $\geq 50 \mathrm{~mm}$ & 27 & 18 & 9 & 0.112 \\
\hline$<50 \mathrm{~mm}$ & 24 & 10 & 14 & & $<50 \mathrm{~mm}$ & 24 & 11 & 13 & \\
\hline Vascular invasion & 51 & & & & Vascular invasion & 51 & & & \\
\hline Yes & 19 & 10 & 8 & 0.346 & Yes & 19 & 20 & 8 & $0.021^{\mathrm{a}}$ \\
\hline No & 32 & 15 & 18 & & No & 32 & 9 & 14 & \\
\hline Capsular infiltration & 51 & & & & Capsular infiltration & 51 & & & \\
\hline Yes & 8 & 4 & 4 & 0.626 & Yes & 8 & 6 & 2 & 0.233 \\
\hline No & 43 & 21 & 22 & & No & 43 & 23 & 20 & \\
\hline $\begin{array}{l}\text { AFP before surgery } \\
(\mathrm{ng} / \mathrm{ml})\end{array}$ & 51 & & & & $\begin{array}{l}\text { AFP before surgery } \\
(\mathrm{ng} / \mathrm{ml})\end{array}$ & 51 & & & \\
\hline$\geq 200$ & 29 & 14 & 15 & 0.564 & $\geq 200$ & 29 & 16 & 13 & 0.503 \\
\hline$<200$ & 22 & 11 & 11 & & $<200$ & 22 & 13 & 9 & \\
\hline Tumor number & 51 & & & & Tumor number & 51 & & & \\
\hline Single & 27 & 13 & 14 & 0.559 & Single & 27 & 16 & 11 & 0.467 \\
\hline Multiple & 24 & 12 & 12 & & Multiple & 24 & 13 & 11 & \\
\hline BCLC stage & 51 & & & & BCLC stage & 51 & & & \\
\hline $\mathrm{A}$ & 17 & 4 & 13 & $0.011^{\mathrm{a}}$ & A & 17 & 7 & 10 & 0.097 \\
\hline $\mathrm{B}+\mathrm{C}$ & 34 & 21 & 13 & & $\mathrm{~B}+\mathrm{C}$ & 34 & 22 & 12 & \\
\hline $\begin{array}{l}\text { GCT level before } \\
\text { surgery }\end{array}$ & 51 & & & & $\begin{array}{l}\text { GCT level before } \\
\text { surgery }\end{array}$ & 51 & & & \\
\hline$\geq 54$ & 32 & 15 & 17 & 0.457 & $\geq 54$ & 32 & 18 & 14 & 0.572 \\
\hline$<54$ & 19 & 10 & 9 & & $<54$ & 19 & 11 & 8 & \\
\hline $\begin{array}{l}\text { ALT level before } \\
\text { surgery }\end{array}$ & 51 & & & & $\begin{array}{l}\text { ALT level before } \\
\text { surgery }\end{array}$ & 51 & & & \\
\hline$\geq 40$ & 31 & 19 & 12 & $0.028^{\mathrm{a}}$ & $\geq 40$ & 31 & 20 & 11 & 0.139 \\
\hline$<40$ & 20 & 6 & 14 & & $<40$ & 20 & 9 & 11 & \\
\hline Intrahepatic metastasis & 51 & & & & Intrahepatic metastasis & 51 & & & \\
\hline Yes & 31 & 17 & 14 & 0.228 & Yes & 31 & 21 & 10 & $0.048^{\mathrm{a}}$ \\
\hline No & 20 & 8 & 12 & & No & 20 & 8 & 12 & \\
\hline
\end{tabular}

while it had no significant difference in groups in terms of gender, age, Childs classification, AFP level, tumor size, tumor number and presence of cancer capsule (Table IV, $\mathrm{P}>0.05$ ).
Table IV. COX-2 expression was statistically different between HCC patients with vascular invasion and without vascular invasion, and HCC patients with intrahepatic metastasis and without intrahepatic metastasis $(\mathrm{P}=0.021$ and $\mathrm{P}=0.048$, respectively).

Reduced survival time in HCC patients with positive expression of HIF-1 $\alpha$ and COX-2 protein. Kaplan-Meier test showed that the median survival time of HCC patients with positive 


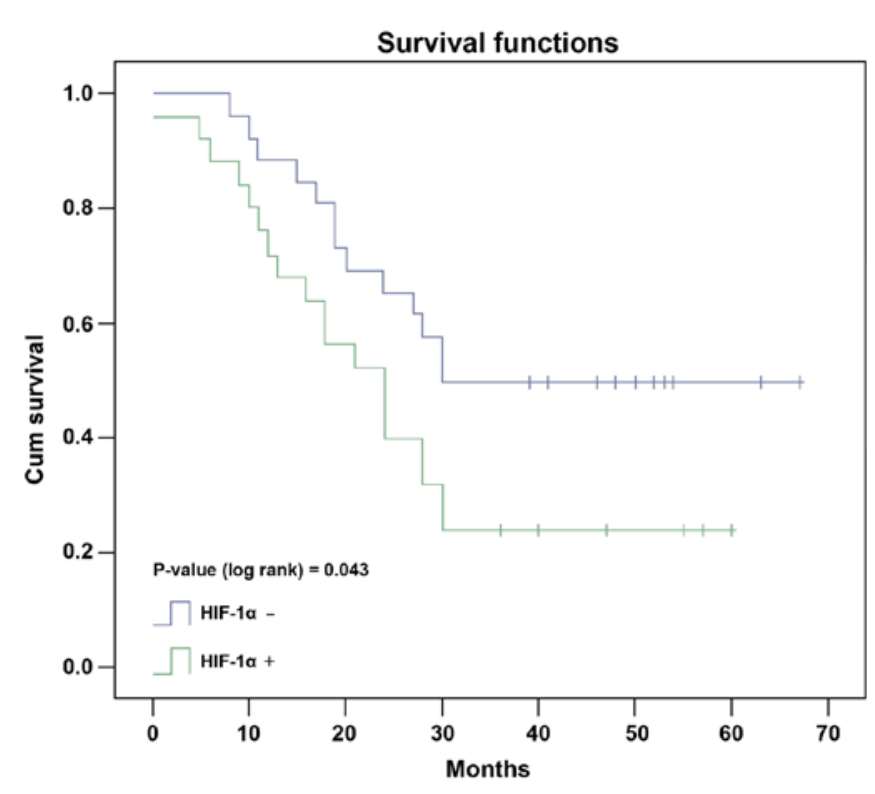

Figure 3. Kaplan-Meier analysis. The median survival time of HCC patients with positive expression of HIF-1 $\alpha$ protein was 28.0 months, which was significantly shorter than the median survival time of 45.0 months in HCC patients with negative expression of HIF-1 $\alpha$ protein.

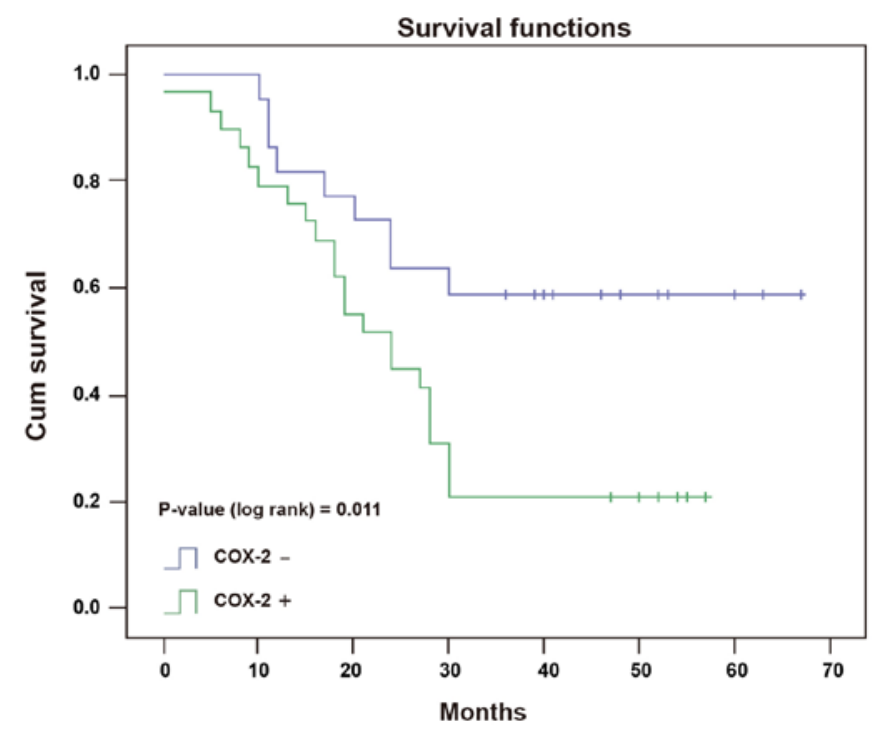

Figure 4. Kaplan-Meier analysis. The median survival time of HCC patients with positive expression of COX-2 protein was 26.0 months, which was significantly shorter than the median survival time of 46.0 months in HCC patients with negative expression of COX-2 protein.

HIF-1 $\alpha$ protein detection was 27.0 months, significantly shorter than that of 43.0 months in patients with negative HIF-1 $\alpha$ protein detection (Fig. 3, $\mathrm{P}=0.043$, log-rank test). In parallel, the median survival time in COX-2 positive patients was 26.0 months, which was significantly shorter than that of 46.0 months in COX-2 negative patients (Fig. 4, $\mathrm{P}=0.011$, log-rank test).

Intrahepatic metastasis, tumor size and $\mathrm{COX}-2$ protein expression was associated with prognosis of HCC patients.
Table V. Univariate analysis showed that tumor size, intrahepatic metastasis, vascular invasion, positive expression of HIF- $1 \alpha$ and COX-2 $\alpha$ and double-positive expression of HIF- $1 \alpha$ plus COX-2 were correlated with prognosis of $\mathrm{HCC}$ patients.

\begin{tabular}{llcl}
\hline Clinical characteristics & RR & $95 \%$ CI & P-value \\
\hline Gender & 0.2 & $1.910-2.756$ & 0.650 \\
Age & 1.66 & $1.829-2.836$ & 0.204 \\
Tumor size & 9.99 & $1.250-2.290$ & $0.002^{\mathrm{a}}$ \\
Vascular invasion & 2.168 & $1.210-2.290$ & 0.141 \\
Capsular infiltration & 1.44 & $1.731-2.936$ & 0.230 \\
AFP & 0.9 & $1.341-2.659$ & 0.342 \\
BCLC stage & 1.503 & $1.527-2.473$ & 0.220 \\
Tumor number & 1.55 & $2.249-2.750$ & 0.213 \\
GCT & 0.29 & $2.242-2.758$ & 0.588 \\
ALT & 1.4 & $2.136-2.863$ & 0.228 \\
Intrahepatic metastasis & 7.2 & $1.296-2.205$ & $0.007^{\mathrm{a}}$ \\
HIF-1 $\alpha$ & 4.35 & $1.675-2.325$ & $0.037^{\mathrm{a}}$ \\
COX-2 & 6.4 & $1.271-2.729$ & $0.011^{\mathrm{a}}$ \\
HIF-1 $\alpha+C O X-2$ & 12.07 & $0.928-2.072$ & $0.001^{\mathrm{a}}$ \\
\hline
\end{tabular}

Table VI. Multivariate analysis showed that tumor size, intrahepatic metastasis and COX-2 expression were the most important risk factors for prognosis of HCC patients.

\begin{tabular}{lccc}
\hline Clinical characteristics & RR & $95 \%$ CI & P-value \\
\hline Tumor size & 0.385 & $0.165-0.899$ & $0.027^{\mathrm{a}}$ \\
Intrahepatic metastasis & 0.300 & $0.094-0.954$ & $0.041^{\mathrm{a}}$ \\
Vascular invasion & 2.264 & $0.816-6.279$ & 0.116 \\
HIF-1 $\alpha$ & 0.284 & $0.057-1.419$ & 0.125 \\
COX-2 & 0.242 & $0.070-0.839$ & $0.025^{\mathrm{a}}$ \\
HIF-1 $\alpha+$ COX-2 & 3.157 & $0.515-24.695$ & 0.198 \\
\hline
\end{tabular}

Table VII. HIF-1 $\alpha$ protein expression was positively correlated with $\mathrm{COX}-2$ protein expression $(\mathrm{P}=0.033)$.

\begin{tabular}{lrcr}
\hline & \multicolumn{2}{c}{ HIF-1 $\alpha$} & \\
\cline { 2 - 3 } COX-2 & Positive & Negative & P-value \\
\hline Positive & 18 & 11 & 0.033 \\
Negative & 7 & 15 & \\
\hline
\end{tabular}

Univariate analysis showed that several parameters were associated with poor prognosis of $\mathrm{HCC}$, including tumor size, intrahepatic metastasis, HIF-1 $\alpha$ expression, COX-2 expression and HIF-1 $\alpha /$ COX-2 double expression (Table V). Furthermore, multivariate Cox's proportional hazard regression analysis showed these parameters were independent prognostic factors for HCC patients $(\mathrm{P}=0.011)$, indicating that tumor size, intra- 
Table VIII. HIF-1 $\alpha$ protein expression was positively correlated with Snail and Vimentin protein expression $(\mathrm{P}=0.001$ and 0.007 , respectively), while it was negatively correlated with E-cadherin protein expression $(\mathrm{P}=0.001)$.

\begin{tabular}{lrrrr} 
& \multicolumn{2}{c}{ HIF-1 $\alpha$} & & \\
\cline { 2 - 3 } Snail & Positive & Negative & R value & P-value \\
\hline Positive & 17 & 8 & 0.451 & 0.001 \\
Negative & 8 & 18 & & \\
\hline
\end{tabular}

\begin{tabular}{lrrrr} 
& \multicolumn{2}{c}{ HIF-1 $\alpha$} & & \\
\cline { 2 - 3 } Vimentin & Positive & Negative & R value & P-value \\
\hline Positive & 18 & 9 & 0.347 & 0.007 \\
Negative & 7 & 17 & & \\
\hline
\end{tabular}

\begin{tabular}{lrrrr}
\hline & \multicolumn{3}{c}{ HIF-1 $\alpha$} & \\
\cline { 2 - 4 } E-cadherin & Positive & Negative & R value & P-value \\
\hline Positive & 4 & 21 & -0.491 & 0.001 \\
Negative & 21 & 5 & & \\
\hline
\end{tabular}

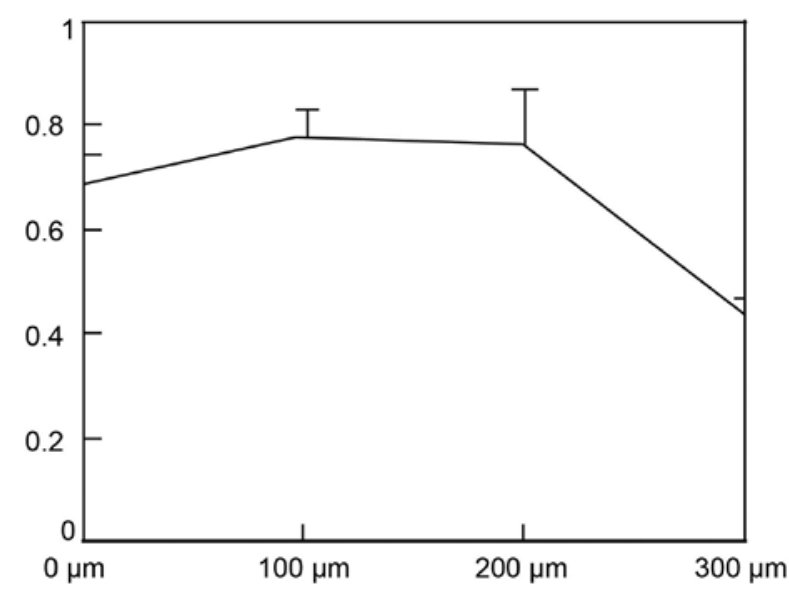

Figure 5. HepG2 cell viability significantly decreased after treatment with $\mathrm{CoCl}_{2}$ at high concentration for $24 \mathrm{~h}$. hepatic metastasis and COX-2 protein expression were closely associated with poor prognosis of HCC patients (Table VI).

The positive correlation between $H I F-1 \alpha$ and $C O X-2$ protein expression. The positive rate of COX-2 protein expression in HCC patients with HIF-1 $\alpha$ positive expression was $72.7 \%$ $(18 / 25)$, which was higher than that of $42.3 \%(11 / 26)$ in HIF-1 $\alpha$ negative HCC patients. Whereas, the positive rate of HIF-1 $\alpha$ protein expression in HCC patients with COX-2 positive expression was higher than that of HCC patients without detectable COX-2 expression [62.1\% (18/29) and 31.8\% (7/22), respectively]. Spearman rank correlation analysis showed that there was a positive correlation between HIF-1 $\alpha$ and COX-2 protein expression (Table VII, $\mathrm{P}=0.033$ ).

HIF-1 $\alpha$ is positively correlated with Snail protein positive expression, while it is negatively correlated with Vimentin protein positive expression. The positive rates of Snail, Vimentin and E-cadherin protein expression in HCC patients with HIF-1 $\alpha$ positive expression were $68 \%$ (17/25), $72 \%$ $(18 / 25)$ and $16 \%(4 / 25)$, respectively. In contrast, the positive rate of these 3 proteins was $30.8 \%(8 / 26), 34.6 \%(9 / 26)$ and $80.7 \%(21 / 26)$, respectively, in patients without detectable HIF-1 $\alpha$ expression. Spearman rank correlation analysis showed that HIF-1 $\alpha$ expression was positively correlated with Snail and Vimentin protein expression (Table VIII, $\mathrm{P}=0.007$ ), while it was negatively correlated with E-cadherin expression (Table VIII, $\mathrm{P}=0.001$ ).

$\mathrm{CoCl}_{2}$ decreases HepG2 cell viability. After treated with $\mathrm{CoCl}_{2}$ at concentration of 100 and $200 \mu \mathrm{M}$ for $24 \mathrm{~h}, \mathrm{HepG} 2$ cell viability had no significant difference compared with control group (treated with $0 \mu \mathrm{M} \mathrm{CoCl}_{2}$, Fig. 5, P>0.05). After treated with $300 \mu \mathrm{M} \mathrm{CoCl}_{2}$ for $24 \mathrm{~h}$, cell viability significantly decreased, compared with control group (Fig. 5, $\mathrm{P}=0.001$ ).

$\mathrm{CoCl}_{2}$ treatments promote HepG2 cell invasion and migration in vitro. After treated with $\mathrm{CoCl}_{2}$ for $24 \mathrm{~h}$, the mean number of HepG2 cells migrated through Matrigel was significantly higher than that of control group (Fig. 6, $\mathrm{P}<0.001$ ). Moreover, after treated with $\mathrm{CoCl}_{2}$ for 24 and $48 \mathrm{~h}$, HepG2 cell migration was significantly enhanced in a time-dependent manner (Fig. 7, P<0.001).
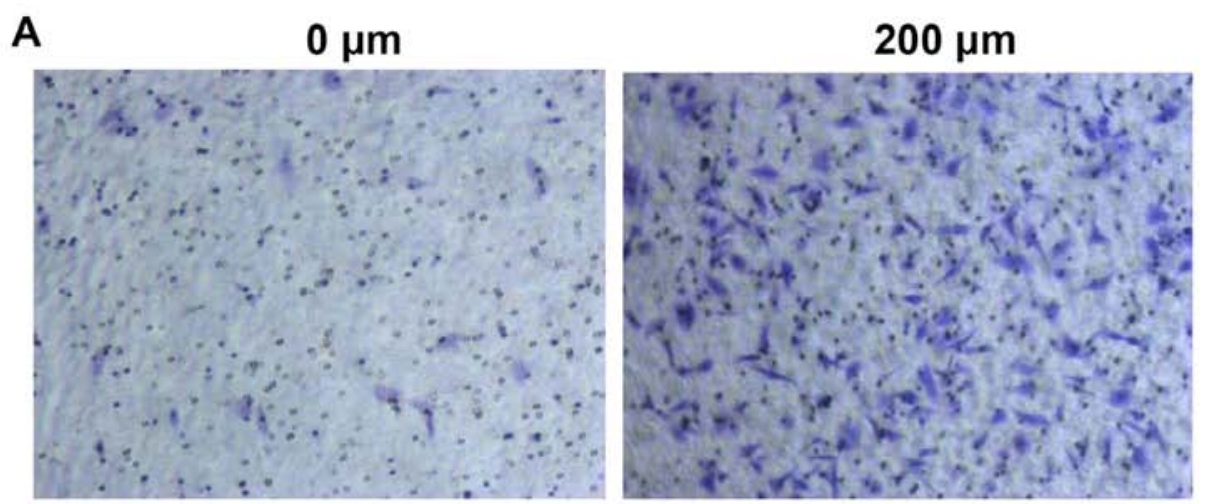

B

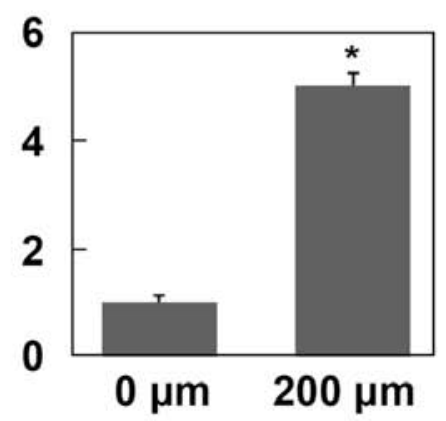

Figure 6. The ability of invasion of HepG2 cells was enhanced after treatment with $200 \mu \mathrm{M} \mathrm{CoCl}_{2}$. 


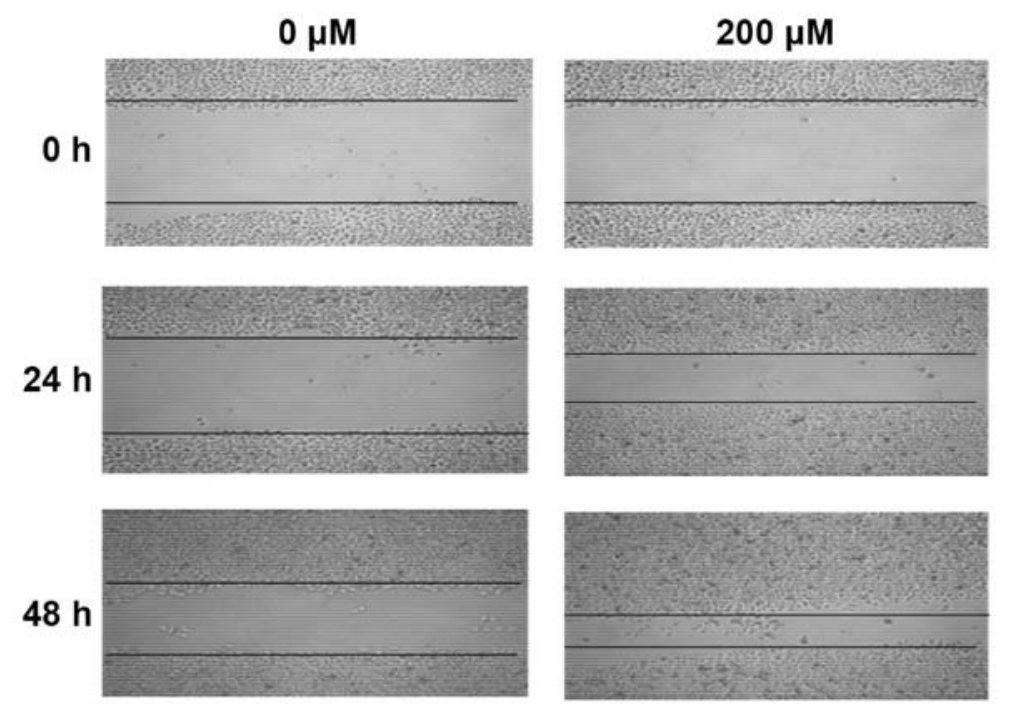

Figure 7. Wound healing assay showing that $\mathrm{CoCl}_{2}$ treatment promoted $\mathrm{HepG} 2$ cell migration.

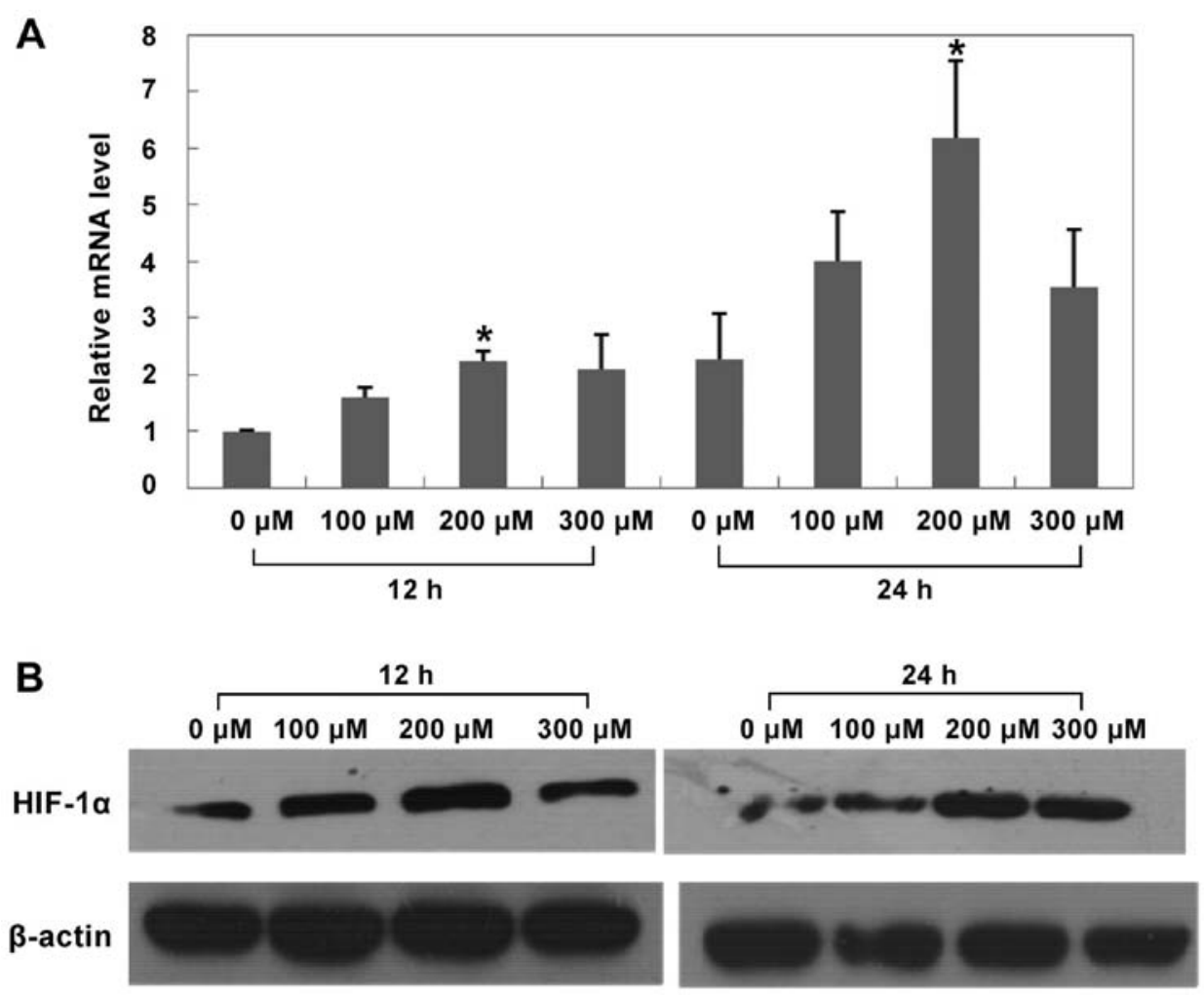

Figure 8. The results of qRT-PCR show that expression of HIF- $1 \alpha$ mRNA increased after treated with $\mathrm{CoCl}_{2}$ in a concentration-dependent manner and reached a peak value when treated with $200 \mu \mathrm{M} \mathrm{CoCl}_{2}$ for $24 \mathrm{~h}$ (A). Consistent with mRNA expression results, $\mathrm{HIF}-1 \alpha$ protein expression induced by CoCl ${ }_{2}$ also increased in a concentration-dependent manner (B).

Effects of $\mathrm{CoCl}_{2}$ treatment on $\mathrm{HIF}-1 \alpha, \mathrm{COX}-2$ and EMT protein expression in HepG2 cells. After treated with $\mathrm{CoCl}_{2}$ at different concentrations for $12 \mathrm{~h}$ and $24 \mathrm{~h}$, both mRNA and protein expression of HIF- $1 \alpha$ and COX-2 significantly increased in the $200 \mu \mathrm{M} \mathrm{CoCl}_{2}$ treatment group (Figs. 8 and 9, $\mathrm{P}<0.05$ versus control group). Furthermore, after treated with $200 \mu \mathrm{M} \mathrm{CoCl}_{2}$ for $24 \mathrm{~h}$, we found that E-cadherin protein expression significantly increased compared with control group (Fig. 10, $\mathrm{P}<0.05$ ), while Vimentin and Snail protein expression decreased compared with control group (Fig. 10, $\mathrm{P}<0.05)$.

\section{Discussion}

The clinical significance of HIF-1 $\alpha, C O X-2$ and EMT in $H C C$ patients after TACE surgery. TACE is considered as an important interventional therapeutic approach to treat patients with hepatocellular carcinoma (HCC). It has several advan- 
A

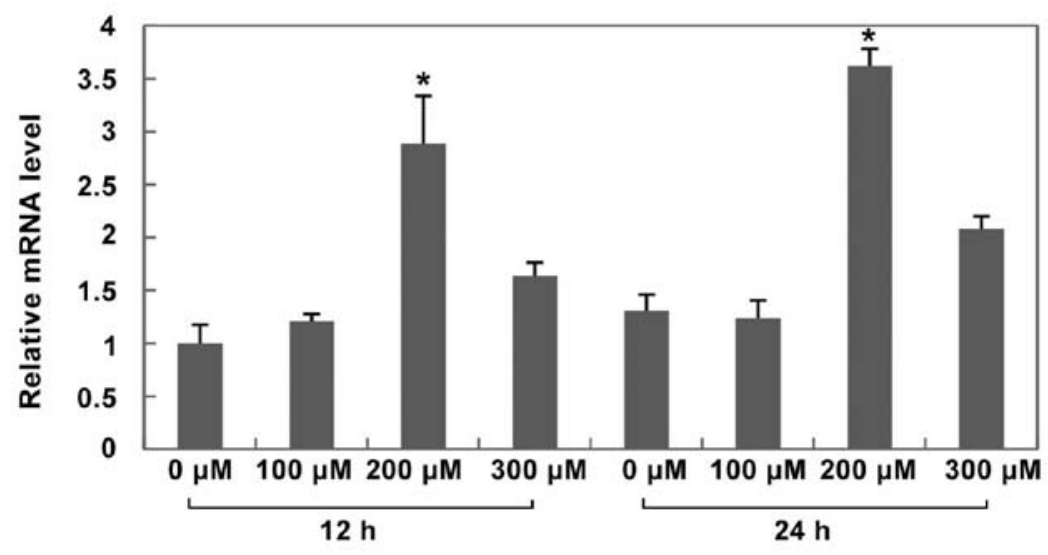

B
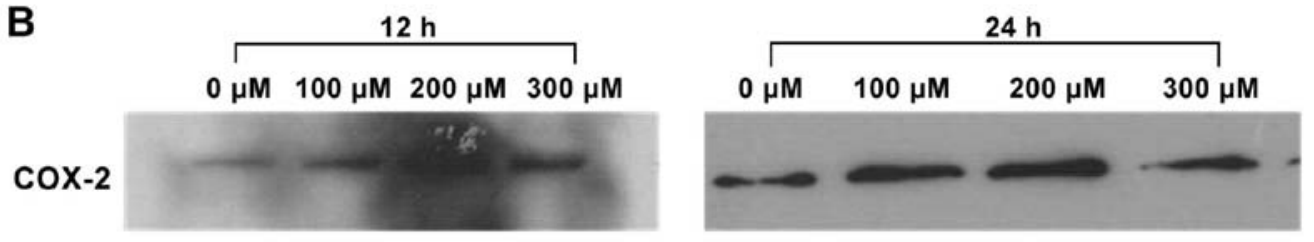

$\beta$-actin
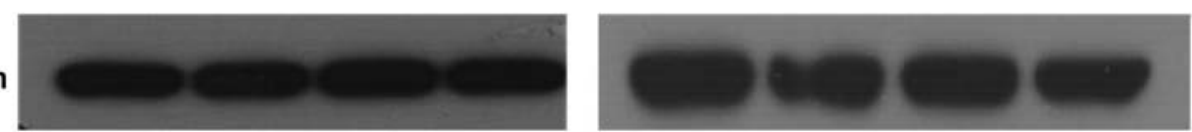

Figure 9. The results of qRT-PCR show that expression of COX-2 mRNA increased after treated with $\mathrm{CoCl}_{2}$ in a concentration-dependent manner and reached a peak value when treated with $200 \mu \mathrm{M} \mathrm{CoCl}_{2}$ for $24 \mathrm{~h}$ (A). Consistent with mRNA expression results, COX-2 protein expression induced by CoCl ${ }_{2}$ also increased in a concentration-dependent manner (B).

A

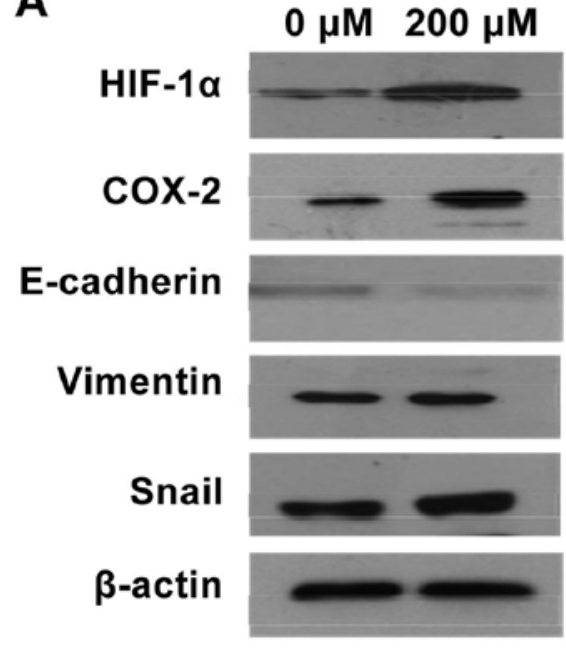

B

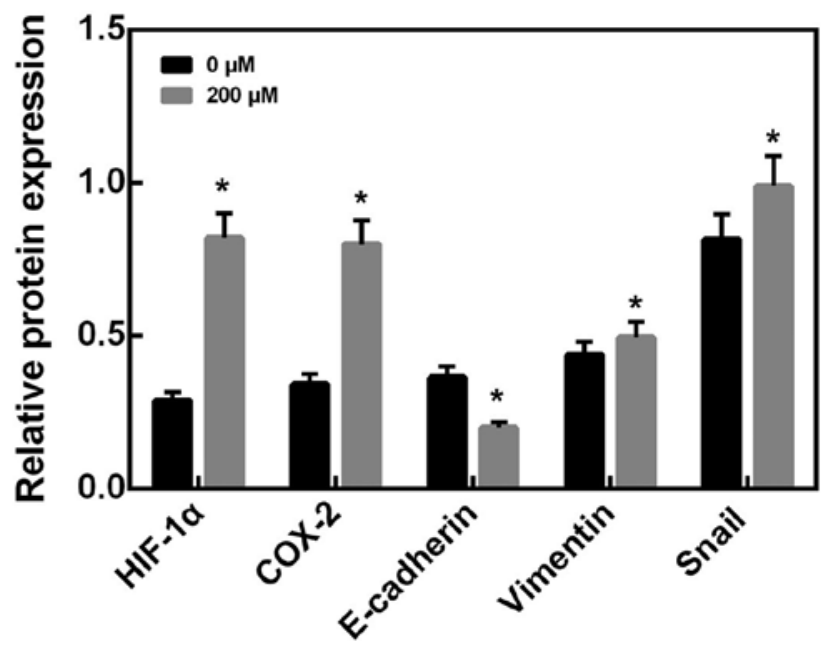

Figure 10. The results of western blot analysis show that hypoxia induced by $\mathrm{CoCl}_{2}$ treatment significantly enhanced HIF-1 $\alpha$, COX-2, Snail and Vimentin protein expression, while it reduced EMT-relevant E-cadherin protein expression.

tages, e.g., it is a minimal invasive procedure rendering short recovery time for patients, and it is tumor-targeted causing fewer side effects. However, in many cases tumor cells can adapt to the highly anaerobic microenvironment resulted from TACE through the negative feed-back response (32). HIF-1 $\alpha$, induced by hypoxia and found to be expressed in many solid tumors, regulates an array of genes to adapt to hypoxic environment, which promotes tumor growth and metastasis. Increased
HIF-1 $\alpha$ protein expression has been found in prostate cancer, head and neck cancer, ovarian cancer, breast cancer and hepatocellular carcinoma $(16,33,34)$. COX-2 gene whose expression can be induced by HIF-1 $\alpha$ has been shown to be upregulated in a variety of malignant tumors and associated with tumor growth and development (20). In this study, we found that the protein levels of HIF-1 $\alpha$ and COX-2 in HCC tissue from patients after TACE surgery was significantly higher than that 
of adjacent normal liver tissue and cancer tissue from HCC patients without TACE surgery. Moreover, after TACE surgery HCC patients with HIF-1 $\alpha$ and COX-2 expression had shorter survival time than HCC patients who were HIF-1 $\alpha$ and COX-2 negative, indicating that both protein detections might be helpful for the evaluation of prognosis of HCC patients who had TACE. Further analysis also suggested that the prognosis of HCC patients post TACE was related to tumor size, intrahepatic metastasis and COX-2 expression, which were found to be independent prognostic factors for HCC patients. We were unable to conclude that HIF-1 $\alpha$ was the most important prognostic factor for HCC patients, which might be due to the small sample size of this study. It is known that TACE triggers inflammatory reactions that we speculated might be the most important prognostic factor, which merits further studies.

In recent years, studies have found that COX-2 is probably a downstream gene in HIF-1 $\alpha$ signaling pathway, and its expression is modulated by HIF-1 $\alpha$ through the regulation of the specific HRE sequence in the COX-2 promoter $(35,36)$. Both HIF-1 $\alpha$ and COX-2 play a key role in the adaptation of hypoxic environment for cancer cells. Our study also showed that HIF-1 $\alpha$ expression was positively correlated to COX-2 expression, suggesting that $\mathrm{HIF}-1 \alpha$ might regulate $\mathrm{COX}-2$ expression and subsequently affect the prognosis of $\mathrm{HCC}$ patients after TACE. The details of the regulatory mechanism remains to be explored.

EMT is considered as a key mechanism for tumor recurrence and metastasis. Decreased expression of E-cadherin in the EMT process leads to reduced cell adhesion and thus enhanced tumor cell migration (37). Snail, a key inducing factor of EMT, enhances tumor cell invasion through downregulation of E-cadherin and upregulation of some other related-proteins $(38,39)$. Vimentin, a biomarker of EMT, also is involved in tumor invasion and metastasis and its increased expression is associated with poor prognosis of tumor patients (40). In this study, we found that HIF-1 $\alpha$ was positively correlated to Snail and Vimentin expression while negatively correlated to E-cadherin expression. Our data suggested that HIF-1 $\alpha$ expression might promote cancer cell EMT, regulate cell motility and migration, and thus affect prognosis of HCC patients after TACE surgery.

Effects of hypoxia on HIF-1 $\alpha, C O X-2$ expression and EMT alteration in HepG2 cells. We found that HIF-1 $\alpha$ and COX-2 expression increased in tumor tissues from HCC patients after TACE surgery. We further established a hypoxic cell model in vitro induced by $\mathrm{CoCl}_{2}$ treatment. The results showed that both mRNA and protein expression of HIF-1 $\alpha$ and COX-2 in HepG2 cell increased after $\mathrm{CoCl}_{2}$ treatment. EMT plays an important role in tumor development and metastasis (27). Studies have shown that both cancer invasion and migration were related to the EMT process $(30,41)$. Consistent with our clinical study results, in vitro study showed that deceased E-cadherin expression and increased expression of Vimentin and Snail were accompanied by enhanced HIF-1 $\alpha$ and COX-2 expression induced by hypoxia. Moreover, hypoxia induced by $\mathrm{CoCl}_{2}$ increased the ability of tumor invasion and migration. Our data indicated that increased expression of HIF-1 $\alpha$ and COX-2 resulted from hypoxia promoted cancer cell EMT alteration and thus its ability of invasion and migration, which probably is an important factor contributing to the recurrence of HCC after TACE surgery.

In conclusion, taken together, our clinical and in vitro data suggest that TACE produced-hypoxic environment induces HIF-1 $\alpha$ expression upregulating COX-2 to promote cancer angiogenesis, inhibiting cancer cell apoptosis and enhancing cancer invasion and migration (20). In addition, increased HIF-1 $\alpha$ expression induces EMT alteration, which enhances cancer cell migration and invasion. All these factors might contribute to the poor prognosis of HCC patients post TACE.

\section{Acknowledgements}

We thank Professor Zhao-Xing Pan for his kindly statistical advice to this manuscript. This study has received funding by the National Natural Science Foundation of China (81172193 and 81430041).

\section{References}

1. Bruix $\mathrm{J}$ and Sherman M; American Association for the Study of Liver Diseases: Management of hepatocellular carcinoma: An update. Hepatology 53: 1020-1022, 2011.

2. Curado M, Edwards B and Shin H: Cancer Incidence in Five Continents. IARC Sci Publ, Lyon, 2007.

3. Ferlay J, Shin HR, Bray F, Forman D, Mathers C and Parkin DM: Estimates of worldwide burden of cancer in 2008: GLOBOCAN 2008. Int J Cancer 127: 2893-2917, 2010.

4. Okuda K: Hepatocellular carcinoma. J Hepatol 32 (Suppl): 225-237, 2000.

5. Cammà C, Schepis F, Orlando A, Albanese M, Shahied L, Trevisani F, Andreone P, Craxì A and Cottone M: Transarterial chemoembolization for unresectable hepatocellular carcinoma: Meta-analysis of randomized controlled trials. Radiology 224: 47-54, 2002.

6. Llovet JM, Real MI, Montaña X, Planas R, Coll S, Aponte J, Ayuso C, Sala M, Muchart J, Solà R, et al; Barcelona Liver Cancer Group: Arterial embolisation or chemoembolisation versus symptomatic treatment in patients with unresectable hepatocellular carcinoma: A randomised controlled trial. Lancet 359: 1734-1739, 2002.

7. Maluccio MA, Covey AM, Porat LB, Schubert J, Brody LA, Sofocleous CT, Getrajdman GI, Jarnagin W, Dematteo R, Blumgart LH, et al: Transcatheter arterial embolization with only particles for the treatment of unresectable hepatocellular carcinoma. J Vasc Interv Radiol 19: 862-869, 2008.

8. Saharinen P, Eklund L, Pulkki K, Bono P and Alitalo K: VEGF and angiopoietin signaling in tumor angiogenesis and metastasis. Trends Mol Med 17: 347-362, 2011.

9. Xu W, Kwon JH, Moon YH, Kim YB, Yu YS, Lee N, Choi KY, Kim YS, Park YK, Kim BW, et al: Influence of preoperative transcatheter arterial chemoembolization on gene expression in the HIF-1 $\alpha$ pathway in patients with hepatocellular carcinoma. J Cancer Res Clin Oncol 140: 1507-1515, 2014.

10. Dai CX, Gao Q, Qiu SJ, Ju MJ, Cai MY, Xu YF, Zhou J,Zhang BH and Fan J: Hypoxia-inducible factor-1 alpha, in association with inflammation, angiogenesis and MYC, is a critical prognostic factor in patients with HCC after surgery. BMC Cancer 9: 418, 2009.

11. Semenza GL: Hypoxia-inducible factor 1: Oxygen homeostasis and disease pathophysiology. Trends Mol Med 7: 345-350, 2001.

12. Valencak J, Kittler H, Schmid K, Schreiber M, Raderer M, Gonzalez-Inchaurraga $\mathrm{M}$, Birner $\mathrm{P}$ and Pehamberger $\mathrm{H}$ : Prognostic relevance of hypoxia inducible factor-1alpha expression in patients with melanoma. Clin Exp Dermatol 34: e962-e964, 2009.

13. Hirota K: Hypoxia-inducible factor 1, a master transcription factor of cellular hypoxic gene expression. J Anesth 16: 150-159, 2002.

14. Klatte T, Seligson DB, Riggs SB, Leppert JT, Berkman MK, Kleid MD, Yu H, Kabbinavar FF, Pantuck AJ and Belldegrun AS: Hypoxia-inducible factor 1 alpha in clear cell renal cell carcinoma. Clin Cancer Res 13: 7388-7393, 2007. 
15. Miyoshi A, Kitajima Y, Ide T, Ohtaka K, Nagasawa H, Uto Y, Hori $\mathrm{H}$ and Miyazaki K: Hypoxia accelerates cancer invasion of hepatoma cells by upregulating MMP expression in an HIF-1alphaindependent manner. Int J Oncol 29: 1533-1539, 2006.

16. Wu XZ, Xie GR and Chen D: Hypoxia and hepatocellular carcinoma: The therapeutic target for hepatocellular carcinoma. J Gastroenterol Hepatol 22: 1178-1182, 2007.

17. Marnett LJ: Cyclooxygenase mechanisms. Curr Opin Chem Biol 4: 545-552, 2000.

18. Smith WL, DeWitt DL and Garavito RM: Cyclooxygenases: Structural, cellular, and molecular biology. Annu Rev Biochem 69: 145-182, 2000 .

19. Wang D and Dubois RN: Prostaglandins and cancer. Gut 55: $115-122,2006$

20. Yang Y, Zhu J, Gou H, Cao D, Jiang M and Hou M: Clinical significance of Cox-2, Survivin and Bcl-2 expression in hepatocellular carcinoma (HCC). Med Oncol 28: 796-803, 2011.

21. Erdem H, Gündogdu C and Sipal S: Correlation of E-cadherin, VEGF, COX-2 expression to prognostic parameters in papillary thyroid carcinoma. Exp Mol Pathol 90: 312-317, 2011.

22. Raspollini MR, Amunni G, Villanucci A, Boddi V, Baroni G, Taddei A and Taddei GL: Expression of inducible nitric oxide synthase and cyclooxygenase-2 in ovarian cancer: Correlation with clinical outcome. Gynecol Oncol 92: 806-812, 2004.

23. Shi H, Xu JM, Hu NZ and Xie HJ: Prognostic significance of expression of cyclooxygenase-2 and vascular endothelial growth factor in human gastric carcinoma. World J Gastroenterol 9: $1421-1426,2003$

24. Karray-Chouayekh S, Trifa F, Khabir A, Boujelbene N Sellami-Boudawara T, Daoud J, Frikha M, Gargouri A and Mokdad-Gargouri R: Methylation status and overexpression of COX-2 in Tunisian patients with ductal invasive breast carcinoma. Tumour Biol 32: 461-468, 2011.

25. Lim SC, Lee TB, Choi CH, Ryu SY, Min YD and Kim KJ: Prognostic significance of cyclooxygenase-2 expression and nuclear p53 accumulation in patients with colorectal cancer. J Surg Oncol 97: 51-56, 2008.

26. Shamma A, Yamamoto H, Doki Y, Okami J, Kondo M, Fujiwara Y, Yano M, Inoue M, Matsuura N, Shiozaki H, et al: Up-regulation of cyclooxygenase-2 in squamous carcinogenesis of the esophagus. Clin Cancer Res 6: 1229-1238, 2000.

27. Kalluri R and Weinberg RA: The basics of epithelial-mesenchymal transition. J Clin Invest 119: 1420-1428, 2009.

28. Thiery JP and Sleeman JP: Complex networks orchestrate epithelial-mesenchymal transitions. Nat Rev Mol Cell Biol 7: 131-142, 2006.

29. Copple BL: Hypoxia stimulates hepatocyte epithelial to mesenchymal transition by hypoxia-inducible factor and transforming growth factor-beta-dependent mechanisms. Liver Int 30: 669-682, 2010 .
30. Miladi-Abdennadher I, Abdelmaksoud-Dammak R, AyedGuerfali DB, Ayadi L, Khabir A, Amouri A, Frikha F, Tahri N, Ellouz S, Frikha M, et al: Expression of COX-2 and E-cadherin in Tunisian patients with colorectal adenocarcinoma. Acta Histochem 114: 577-581, 2012.

31. Zhang YB, Wang X, Meister EA, Gong KR, Yan SC, Lu GW, Ji XM and Shao G: The effects of $\mathrm{CoCl}_{2}$ on HIF-1 $\alpha$ protein under experimental conditions of autoprogressive hypoxia using mouse models. Int J Mol Sci 15: 10999-11012, 2014.

32. Wang B, Xu H, Gao ZQ, Ning HF, Sun YQ and Cao GW: Increased expression of vascular endothelial growth factor in hepatocellular carcinoma after transcatheter arterial chemoembolization. Acta Radiol 49: 523-529, 2008.

33. Semenza GL: Hypoxia-inducible factors: Mediators of cancer progression and targets for cancer therapy. Trends Pharmacol Sci 33: 207-214, 2012.

34. Yang MH, Wu MZ, Chiou SH, Chen PM, Chang SY, Liu CJ, Teng SC and Wu KJ: Direct regulation of TWIST by HIF-1alpha promotes metastasis. Nat Cell Biol 10: 295-305, 2008.

35. Kaidi A, Qualtrough D, Williams AC and Paraskeva C: Direct transcriptional up-regulation of cyclooxygenase-2 by hypoxiainducible factor (HIF)-1 promotes colorectal tumor cell survival and enhances HIF-1 transcriptional activity during hypoxia. Cancer Res 66: 6683-6691, 2006.

36. Schmedtje JF Jr, Ji YS, Liu WL, DuBois RN and Runge MS: Hypoxia induces cyclooxygenase-2 via the NF-kappaB p65 transcription factor in human vascular endothelial cells. J Biol Chem 272: 601-608, 1997.

37. Hashiguchi $M$, Ueno S, Sakoda M, Iino S, Hiwatashi K, Minami K, Ando K, Mataki Y, Maemura K, Shinchi H, et al: Clinical implication of ZEB-1 and E-cadherin expression in hepatocellular carcinoma (HCC). BMC Cancer 13: 572, 2013.

38. Liu S, Kumar SM, Martin JS, Yang R and Xu X: Snail1 mediates hypoxia-induced melanoma progression. Am J Pathol 179: 3020-3031, 2011

39. Woo HY, Min AL, Choi JY, Bae SH, Yoon SK and Jung CK: Clinicopathologic significance of the expression of Snail in hepatocellular carcinoma. Korean J Hepatol 17: 12-18, 2011.

40. Shirahata A, Sakata M, Sakuraba K, Goto T, Mizukami H, Saito M, Ishibashi K, Kigawa G, Nemoto H, Sanada Y, et al: Vimentin methylation as a marker for advanced colorectal carcinoma. Anticancer Res 29: 279-281, 2009.

41. Shi Y, Wu H, Zhang M, Ding L, Meng F and Fan X: Expression of the epithelial-mesenchymal transition-related proteins and their clinical significance in lung adenocarcinoma. Diagn Pathol 8: 89,2013 